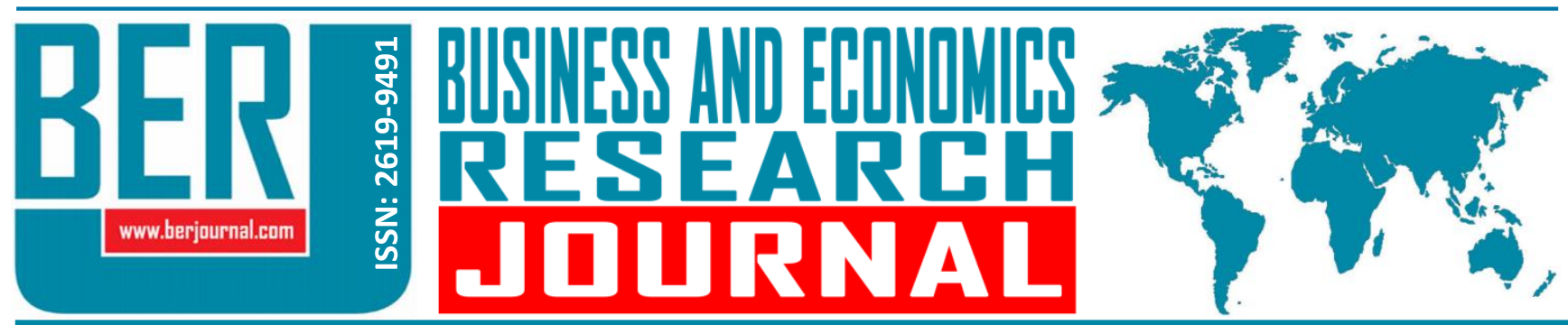

Business and Economics Research Journal Vol. 12, No.1, $2021 \quad$ pp. 111-126 doi: 10.20409/berj.2021.313

\section{Borsa Endeksi, Döviz Kuru, Faiz Oranları ve CDS Primleri Arasındaki Oynaklık Yayılımları: Türkiye Örneği}

\section{Zekai Senol $^{\mathrm{a}}$}

Öz: Son yıllarda, finansal varlıkların oynaklıklarında önemli artışlar görülmektedir. Yüksek oynaklıklar finansal piyasalarda istikrarsızlığa ve portföy risklerinin yükselmesine neden olmaktadır. Bu koşullar altında, oynaklıkları modellemek, oynaklık ilişkilerini ve oynaklık yayılımlarını belirlemek piyasa aktörleri açısından önem taşımaktadır. Bu çalışmada, Türkiye'de, 2 Ocak 2010 - 10 Nisan 2020 döneminde, Borsa istanbul (BIST) 100 endeksi, döviz kuru (\$/E), faiz oranı ve kredi temerrüt takası (CDS) primleri arasındaki oynaklık yayılımları ve oynaklık ilişkileri ile ekonomik, politik ve sosyal faktörlerin korelasyon ilişkisine etkileri araştırılmıştır. Çalışmada, BiST 100 endeksi - döviz kuru, faiz oranı-döviz kuru, CDS primleri - faiz oranı arasında karşılıklı oynaklık yayılımı, CDS primlerinden döviz kuruna doğru tek yönlü oynaklık yayılımı görülmüştür. Faiz oranı - BiST 100 endeksi ve CDS primleri - BiST 100 endeksi arasında negatif oynaklık ilişkisi belirlenirken CDS primleri-faiz oranı ve CDS primleri - döviz kuru arasında ise pozitif oynaklık ilişkisi belirlenmiştir. Ayrıca politik, ekonomik ve sosyal faktörlerin değişkenler arasındaki korelasyon ilişkisini etkilediği tespit edilmiştir.

\section{Volatility Spillover between the Stock Market, Exchange Rates, Interest Rates and CDS Premiums: Evidence from Turkey}

\begin{abstract}
In recent years, the volatility of financial assets has significantly increased. High volatility causes instability in financial markets and increases portfolio risks. Under these conditions, modeling the volatility, determining the volatility relationships, and volatility spillovers are important for market actors. In this study, for the period January 2, 2010 - April 10, 2020, it was investigated the volatility spillover and correlation relationship between the Borsa Istanbul (BIST) 100 Index, the exchange rates (\$/ $/$ ), interest rates, and credit default swap (CDS) premiums. It was also examined the effects of economic, political, and social factors on the correlation relationship. In the study, it was seen that the bidirectional volatility spillover between the BIST 100 index - exchange rates, interest rates - exchange rates, and CDS premiums - interest rates, on the other hand, unidirectional volatility spillover from CDS premiums to the exchange rates. A positive volatility relationship was determined between CDS premiums - interest rates and CDS premiums - exchange rates while the negative volatility relationship between interest rates - BIST 100 index and CDS premiums BIST 100 index. It was also determined that political, economic, and social factors affect the relationships of correlation between variables.
\end{abstract}

Anahtar Sözcükler: Borsalar, Döviz Kurları, Faiz Oranları, CDS Primleri, Oynaklık Yayılımı

JEL: C58, E40, G10, G17

$\begin{array}{ll}\text { Geliş } & : \text { 14 Ağustos } 2020 \\ \text { Düzeltme } & : 05 \text { Ekim 2020 } \\ \text { Kabul } & : \text { 17 Kasım 2020 } \\ \text { Tür } & : \text { Araştırma }\end{array}$

Keywords: Stock Markets, Exchange Rates, Interest Rates, CDS Premiums, Volatility Spillover

JEL: C58, E40, G10, G17

$\begin{array}{ll}\text { Received } & : \text { : } 14 \text { August } 2020 \\ \text { Revised } & : \text { 05 October } 2020 \\ \text { Accepted } & : \text { 17 November } 2020 \\ & \\ \text { Type } & : \text { Research }\end{array}$

a Asst. Prof., PhD., Sivas Cumhuriyet University, Faculty of Economics and Administrative Sciences, Department of Banking and Finance, Sivas, Turkiye, zsenol@cumhuriyet.edu.tr (ORCID ID: 0000-0001-8818-0752) 


\section{Giriş}

Finansal piyasalardaki liberalleşme risk kaynaklarının artmasına neden olmuştur (Kasman, Vardar ve Tunç, 2011: 1328). Günümüzün ekonomik, finansal, politik ve sosyal koşulları çerçevesinde risklerin çeşidi ve etkileri artmıştır. Artan riskler ve risk beklentileri finansal varlık fiyatlarındaki oynaklıkların yükselmesine neden olmaktadır. Oynaklıkların temel nedenleri, küresel ekonomik alanda yaşanan problemler, ekonomik sorunların devam edeceğine yönelik beklentiler, ülkelerin yaşadıkları makroekonomik problemler, siyasi sorunlar, bölgesel ve küresel alandaki riskler şeklinde sıralanabilir. Oynaklığa sebep olan temel etken piyasalara gelen bilgidir. Ross (1989) bilgi akış oranıyla fiyat değişim katsayısının yani oynaklığın eşit olduğunu ifade etmiştir. Piyasalara gelen bilgi sayısı ve niteliğine bağlı olarak oynaklıklarda artış veya azalışlar görülebilmektedir.

Fon yöneticileri yatırım risklerini yönetmek ve yatırımcılara yüksek getiri sağlamak için finansal piyasalardaki değişimler ve bu değişimlere sebep olan etkenlere dikkat etmek durumundadırlar (Fonseca ve Wang, 2016: 1767). Günümüzde oynaklıkların artmasına bağlı olarak finansal piyasalarda oynaklıklara gösterilen ilginin düzeyi yükselmiştir. Bu bakımdan akademik literatürde oynaklıkların modellenmesi, tahmin edilmesi, oynaklık nedenlerinin belirlenmesi gibi çalışmalarda artışlar görülmektedir.

Literatürde döviz kurlarıyla pay piyasaları (borsalar) arasında akış ve stok yönelimli yaklaşımlar bulunmaktadır. Akış yönelimli yaklaşım, ülkelerin uluslararası rekabeti ve dış ticaret dengesinin döviz kurlarını etkilediğini ifade etmektedir (Dornbusch ve Fischer, 1980). Bu modelde, ulusal paranın değer kaybetmesiyle döviz kurlarında meydana gelen artışlar ihracatı teşvik etmekte ve özellikle ihracatçı firmalar başta olmak üzere firma satışlarının artmasıyla pay fiyatları yükselmektedir. Bu yaklaşıma göre döviz kurlarıyla pay fiyatları arasında pozitif yönde ilişki bulunmaktadır. Stok yönelimli modelde döviz kurları sermaye hareketleri yoluyla döviz kurlarını etkilemektedir (Frankel, 1992). Ülkelerin sermaye piyasalarına yatırım amaçlı gelen uluslararası yatırımlar döviz kurlarının düşmesine neden olmaktadır. Stok yönelimli yaklaşımda borsalardan döviz kurlarına doğru negatif yönde etki görülebilmektedir. Bu konuda, Black (2015) döviz kuru getirilerinin finansal fon akımlarıyla pozitif, ticari fon akımlarıyla negatif yönde ilişkili olduğunu ifade etmiştir.

Kredi temerrüt takası (credit default swaps-CDS) primleri 1990'ların sonu, 2000'li yılların başında banka bilançolarında bulunan risklerin başta sigorta şirketleri ve yatırımcılar olmak üzere üçüncü kişilere aktaran risk transfer aracı olarak ortaya çıkmıştır (Mateev, 2019: 1). Finansal sistemin gelişiminde kredi türev piyasalarının önemli rolü olmuş ve CDS'ler kredi türev piyasaları içinde en popüler ve likit araç olarak yer almaktadır (Hurduzeu, Musetescu ve Meghisan, 2015: 152). Kredi temerrüt takası (CDS), referans bir varlığa ilişkin yükümlülüklerin yerine getirilmemesi riskine karşılık, koruma alan ile koruma satan arasında düzenlenen, aldığı prim karşılığında koruma satan tarafın, sözleşmede belirtilen risklerin gerçekleşmesi halinde koruma alan tarafa ödeme yapmayı taahhüt ettiği sözleşmedir.

CDS sözleşmesi ile sigorta sözleşmesini satın alan taraf, referans kuruluşa ait temerrüt riskini sigorta sözleşmesini satan tarafa transfer etmiş olmaktadır. Bu haliyle sigorta poliçesine benzeyen bu işlemde CDS sözleşmesini satın alan tarafın sigorta sözleşmesindeki gibi varlığa sahip olmasına gerek yoktur (Gök ve Arslan, 2019: 302). Dayanak varlığın kredi riskleri arttığında genellikle CDS primleri artmaktadır. Bu nedenle CDS primleri dayanak varlığa sahip kurum ve otoritelerin kredi riskini ölçüm birimi olarak yorumlanmaktadır. Her ülkenin hükümeti tarafından yabancı para cinsinden çıkarılan tahvil bazında hesaplanan CDS primleri o ülkenin kredi riskini gösteren bir araç olarak kullanılmaktadır (I, 2015: 276).

CDS primleri ekonomiler ve piyasalarla ilgili koşulları yansıtmakta ve piyasalarda oluşan ya da oluşabilecek şoklar CDS primlerini artırmaktadır (Balcılar, Hammoudeh ve Toparli, 2018: 813). CDS piyasaları finansal piyasalar için fiyat keşfi ve gelecekle ilgili bilgi sağlama işlevi görmektedirler (Shahzad, Aloui ve Jammazi, 2019). CDS'ler, piyasaları etkileyebilecek bütün risk faktörlerini kapsadığından, varlık fiyatlarını etkileyebilecek gelecekle ilgili etkenler CDS primlerinde fiyatlanmaktadır. CDS primleri kredi riskindeki değişimlerin öngörülmesinde erken uyarı sinyali olarak kullanılan bir araçtır. CDS primlerinin sinyal gücü ihraççıla ilgili bütün haberleri anında yansıtmasından meydana gelmektedir (Castellano ve Scaccia, 2014: 286). Bu özelliğinden dolayı CDS primleri ihraççı kurumla ilgili başta kredi riski olmak üzere finansal riskleri yansıtması nedeniyle günümüzde yaygın olarak kullanılan bir araç haline gelmiştir. 
Günümüzde CDS'ler finansal piyasalarda yaygın şekilde finansal risk göstergesi olarak kullanılmaktadırlar. Kredi derecelendirmeye göre daha objektif olarak değerlendirildiğinden CDS'lerin kullanımı son zamanlarda oldukça yaygınlaşmıştır. Pay, döviz, emtia, türev ve kripto piyasalarında yatıımcılar, portföy yöneticileri, analistler, riskten korunmak isteyenler CDS verilerini kullanmaktadırlar. CDS primlerinin riskleri temsil etmelerinden dolayı genel olarak CDS primleriyle pay fiyatları arasında negatif yönde bir ilişki ve CDS primlerindeki artışların oynaklıkları artırması söz konusudur.

Faiz oranları pay senetleri değerinin hesaplanmasında kullanılan iskonto oranının temel belirleyicilerindendir. Faiz oranı ve buna bağlı olarak iskonto oranı arttıkça pay senedinin beklenen getirisi azalmaktadır. Faiz oranlarındaki artış işletmelerin kaynak maliyetini artırabilir. Artan finansman maliyeti nakit akışlarının düzensizleşmesine, finansal risklerin artmasına ve buna bağlı olarak pay getirilerinin azalmasına neden olabilir.

Pay piyasalarıyla faiz oranlarına dayalı borçlanma araçları piyasaları alternatif piyasalardır. Borçlanma araçları piyasalarında genellikle tahvil, finansman bonosu, mevduat gibi faize dayalı araçlar bulunmaktadır. Faiz oranlarındaki artışa bağlı olarak faiz getirisinden yararlanmak isteyen yatırımcılar pay piyasalarından borçlanma araçları piyasalarına yönelebilirler. Faiz artışları borçlanma araçları piyasasına olan ilgiyi artıırken yatırımcıların pay piyasasından uzaklaşmalarına neden olabilir.

Üretime ucuz finansman sağlanması, reel sektörün desteklenmesi, pay sahiplerinin ve firma değerlerin artırıması, ekonomik büyümenin sağlanması bakımından faiz oranlarının düşük ve istikrarı olması önem taşımaktadır. Bu bakımdan para otoritelerinin üretimi teşvik ederken tasarrufları finansal sisteme aktarıcı nitelikte faiz politikası belirlemeleri önemlidir.

Bu çalışmanın amacı, son yıllarda Türkiye'de özellikle döviz başta olmak üzere finansal varlıklarda görülen yüksek oynaklıklar, oynaklık ilişkileri ve oynaklık yayılımlarını incelemek, bu oynaklık ilişkilerinde ekonomik, politik ve diğer faktörlerin rollerini araştırmaktır. Çalışmayı Türkiye örneği çerçevesinde diğer çalışmalardan ayıran bazı özellikler bulunmaktadır. Kasman vd. (2011), Kar, Bayat ve Kayhan (2016), Akkuş, Sakarya ve Tüzün (2018), Yaman ve Korkmaz (2020) ve Bolaman Avcı (2020) çalışmalarında borsa, döviz kuru, faiz oranı ve CDS primleri değişkenlerinin hepsini birlikte kullanmamışlar, söz konusu değişkenlerin bir ya da birkaçı farklı amaçlarla bu çalışmalara konu olmuştur. Bu çalışmada, piyasalarda yaygın olarak kullanılan dört değişkenin birbirleriyle olan oynaklık ilişkileri araştırılarak portföy yönetimi açısından sonuçlar elde edilmeye çalışılmıştır. Yöntem açısından yukarıdaki çalışmalardan farklı olarak oynaklık ilişkileri dinamik koşullu korelasyonlar ve oynaklık yayılımları ise varyansta nedensellik testleriyle araştırılmıştır. Balcılar vd. (2018) çalışmalarında 2008 küresel krizi ve Yunanistan borç krizinin oynaklık ilişkilerine etkisini araştırmışlardır. Bu çalışmada ise, seçimler gibi politik olaylar başta olmak üzere ekonomik ve sosyal olayların oynaklık ilişkilerine etkileri araştırımıştır.

\section{Literatür}

Finansal piyasalarda oynaklıkların artması ve oynaklıkla ilgili yöntemlerin gelişmesine bağlı olarak son yıllarda oynaklık çalışmalarında artışların olduğu görülmektedir. Oynaklık çalışmalarının genelinde günlük gözlem değerleri kullanıldığı için çalışmalarda borsa endeksleri, döviz kurları, altın fiyatları, petrol fiyatları, kripto para fiyatlarının yaygın olarak kullanıldığı anlaşılmaktadır. Çalışmalarda genel olarak, döviz kurları, CDS primleri, faiz oranlarından borsalara doğru oynaklık yayılımlarının olduğu, 2008 küresel krizinden sonra oynaklıklarda artışların görüldüğü, oynaklık ilişkilerinin başta ekonomik gelişmeler olmak üzere çeşitli faktörlerden etkilendiği gözlemlenmiştir.

Bu çalışmayla ilgili literatür, borsalar - döviz kurları, borsalar - CDS primleri, borsalar - faiz oranları, döviz kurları - CDS primleri - faiz oranları arasındaki oynaklık ilişkileri dikkate alınarak incelenebilir. Pay piyasalarıyla döviz kurları arasındaki oynaklıkları esas alan çalışmalar I (2015), Sui ve Sun (2016), Mouna ve Aniz (2017), Morales-Zumaquero ve Sosvilla-Rivero (2018), Tule, Dogo ve Uzonwanne (2018), Zankawah ve Stewart (2019), Siddiqui ve Roy (2019), Signhal, Choudhary ve Biswal (2019) Erdoğan, Gedikli ve Çevik (2020), Yaman ve Korkmaz (2020), Baklacı, Aydoğan, Yelkenci, (2020) ve Dai, Zhou ve Dong (2020) şeklindedir. 
Morales-Zumaquero ve Sosvilla-Rivero (2018) döviz kurlarıyla borsalar arasındaki oynaklık yayılımını endüstrileşmiş yedi ülkede, 1 Ocak 1990 - 31 Aralık 2015 döneminde C-GARCH ve SVAR yöntemleriyle araştırmışlardır. Çalışmada, genellikle döviz kurundan borsalara doğru oynaklık yayılımı olduğu, küresel krizden sonra döviz kurundan borsalara olan oynaklık yayılında artış olduğu, küresel kriz sonrasında uzun dönem oynaklığın kısa dönem oynaklıktan daha fazla olduğu ve genel olarak küresel kriz sonrasında oynaklık yayılımlarının arttığı görülmüştür. Endüstrileşmiş ülkelerle ilgili başka bir çalışmada, Baklacı vd. (2020) 1 Ocak 2009 - 31 Aralık 2017 dönemine ait günlük, 15 dakikalık ve 5 dakikalık veriler ve VAR BEKK GARCH yöntemiyle, işlem seanslarındaki farklılıkları dikkate alarak büyük borsalardaki ( $A B D$, Japonya ve íngiltere) gün içi işlemlerin döviz kurlarına yaptıkları oynaklık yayılımını araştırmışlardır. Çalışma sonuçları, temel borsalardaki oynaklık yayılımlarına Hong Kong Doları, Meksika Pesosu gibi küçük para birimlerinin etkisinin olduğunu, Yen ve Paund'un Tokyo ve Londra borsalarındaki oynaklık yayılımını etkilemediğini, borsaların döviz kurları üzerinde bilgi etkisine sahip olduklarını göstermiştir.

Sui ve Sun (2016) BRICS ülkelerinde döviz kurlarıyla borsalar arasındaki ilişkiyi araştırmışlardır. Uzun dönemde Çin ve Rusya'da döviz kurlarıyla borsalar arasında eşbütünleşme ilişkisi olduğu, etki tepki analizinde ise kısa dönemde BRICS ülkelerinin döviz kurlarında meydana gelen şokların borsa getirilerini negatif etkiledikleri görülmüştür. Gelişmekte olan ülkelerle ilgili başka bir çalışmada, Erdoğan vd. (2020) Hindistan, Malezya ve Türkiye olmak üzere üç İslami borsa ve döviz kuru piyasaları arasındaki oynaklık yayılımlarını araştırmışlardır. Çalışmada sadece Türkiye'de borsadan döviz kuruna doğru oynaklık yayılımı olduğu anlaşılmıştır.

Yukarıdaki çoklu ülke örneklemlerinden başka tek ülke örneklerinde de, borsalar ile döviz kurları arasındaki oynaklıkların incelendiği çalışmalar bulunmaktadır. Tule vd. (2018) Nijerya örneğinde, döviz kuru ile borsa arasındaki oynaklık ilişkisini VARMA-AGARCH yöntemiyle araştırmışlar, yapısal kırılmasız testlerde borsadan döviz kuruna doğru; yapısal kırılmalı testlerde ise iki piyasa arasında karşılıklı oynaklık yayılımı tespit edilmiştir. Zankawah ve Stewart (2019) Ocak 1991 - Aralık 2015 döneminde Gana'da ham petrol fiyatlarıyla döviz kuru ve borsa arasındaki oynaklık yayılımını GARCH BEKK yöntemiyle araştırmışlardır. ABD pay piyasalarından Gana borsası ve döviz kuruna doğru şok yayılımı, petrol ile ABD pay piyasası arasında karşılıklı şok yayılımı ve petrolden Gana döviz kuruna doğru şok yayılımı tespit edilmiştir. Siddiqui ve Roy (2019) ise 1 Nisan 2014 - 28 Mart 2018 döneminde, Hindistan'da, altın, petrol, döviz kuru ve borsa arasındaki oynaklık yayılımını VARMA BEKK GARCH yöntemiyle araştırmışlardır. Hindistan borsasıyla altın ve petrol arasında karşııılı oynaklık yayılımı ve Hindistan borsası - petrol ile altın - petrol arasında pozitif oynaklık ilişkisi tespit edilmiştir. Yaman ve Korkmaz (2020) döviz kurlarıyla Borsa İstanbul (BIST) turizm endeksi arasındaki oynaklık yayılım etkisini, 6 Ocak 1997 - 11 Haziran 2019 döneminde, Diagonal VECH GARCH yöntemiyle araştırmışlar ve BIST turizm endeksiyle döviz kurları arasında oynaklık yayılımı olduğunu tespit etmişlerdir. Signhal vd. (2019) Meksika'da Ocak 2006 - Nisan 2018 döneminde petrol, altın, döviz kuru ve borsa arasındaki ilişkileri yukarıdaki oynaklık modellemelerinden farklı olarak ADRL sınır testiyle araştırmışlardır. Petrol fiyatlarının borsa ve döviz kurunu negatif yönde etkilediği, altının borsayı pozitif etkilediği belirlenmiştir. Dai vd. (2020) Ocak 1989 - Aralık 2018 dönemi ve Hong Kong Borsası örnekleminde döviz kuru oynaklığından borsa oynaklığını tahmin etmişler ve döviz kuru oynaklığından borsa oynaklığı tahminine yönelik güçlü kanıtlar elde etmişlerdir.

Borsa ile döviz kuru değişkenlerine ek olarak, I (2015) CDS primlerini çalışmasına eklerken, Mouna ve Aniz (2017) ise faiz oranını eklemiştir. I (2015) Güney Kore, ABD ve Japonya örnekleminde pay piyasaları, CDS primleri ve döviz kurları arasındaki oynaklık yayıımlarını VAR BEKK GARCH yöntemiyle incelemiştir. Kore'de pay piyasalarıyla CDS piyasaları arasında karşılıklı oynaklık yayılımı olduğu, ABD ve Japonya pay piyasasından Kore pay piyasasına doğru ve $A B D$ döviz piyasasından Kore pay piyasasına doğru oynaklık yayılımı olduğu görülmüştür. Mouna ve Aniz (2017) Avrupa ülkeleri, ABD ve Çin olmak üzere sekiz ülkenin Ocak 2006 - Eylül 2009 dönemindeki verileriyle borsa, faiz oranı ve döviz kurları oynaklıklarının teknoloji ve endüstri sektörlerine etkilerini araştırmışlar ve döviz kuru, borsa ve faiz oranı oynaklıklarının endüstri ve teknoloji sektörünü bazen pozitif, bazen negatif etkilediklerini görmüşlerdir. 
Borsalar ve CDS primlerini çalışmalarında temel olarak kullananlar ise, Belke ve Gokus (2011), Castellano ve Scaccia (2013), Hurduzeu vd. (2015), Fonseca ve Wang (2016), Balcılar vd. (2018), Shear ve Butt (2017), Shahzad vd. (2019), Mateev (2019), Bolaman Avcı (2020) ve Fonseca ve Gottschalk (2020) şeklindedir.

Mateev (2019) 1 Ocak 2012 - 29 Ocak 2016 döneminde 109 Avrupa yatırım şirketi örnekleminde CDS primleriyle pay senetleri oynaklıkları arasındaki ilişkiyi DCC GARCH model ve oynaklık yayılımını ise BEKKGARCH yöntemleriyle araştırmıştır. Çalışmada, pay fiyatlarıyla CDS primleri arasında ilişki olduğu ve CDS primleriyle pay fiyatları arasında karşılıklı oynaklık yayılımı olduğu belirlenmiştir. Hurduzeu vd. (2015) Ocak 2008 - Haziran 2015 dönemi, 33 Avrupa ülkesi örnekleminde, CDS ile borsa oynaklıkları arasındaki ilişkileri, Markov Rejim Dönüşüm modeliyle araştırdıkları çalışmada CDS piyasalarıyla borsalar arasında oynaklık yayııımları olduğu ve oynaklık yayılımlarında makroekonomik olayların etkili olduğu belirlenmiştir.

Castellano ve Scaccia (2013) 2004 - 2010 döneminde yaptıkları çalışmada genel olarak CDS primlerindeki oynaklığın borsalarda oynaklığa yol açtığını, CDS primlerinin borsa oynaklıklarını görmede güvenilir bir araç olduğunu göstermiştir. Fonseca ve Wang (2016) 13 Ekim 2004 - 8 Şubat 2012 dönemde CDS ve pay piyasaları arasındaki ilişkileri araştırmışlardır. Çalışmada, CDS primlerindeki oynaklıkların pay piyasalarını etkilediği, kriz öncesine göre küresel kriz sonrasında piyasalardaki oynaklıkların rejim değişimlerinde daha etkili olduğu anlaşılmıştır. Balcılar vd. (2018) 6 Ocak 2004 - 2 Şubat 2016 tarihlerine ait verilerle petrol, pay piyasaları ve CDS primleri arasındaki oynaklık yayılımını araştırmışlardır. Petrol, pay piyasaları ve CDS primleri arasında oynaklık yayılımı olduğu, bu yayılım ilişkisinin Lehman Brother iflası başta olmak üzere Yunanistan borç krizi gibi ekonomik, politik olaylardan etkilendiği görülmüştür. Benzer şekilde Ural ve Demireli (2015) 27 Ocak 2003 - 4 Kasım 2014 dönemine ait verilerle küresel krizin CDS prim oynaklığına etkisini araştırmışlar ve çalışmada, ülkelerin CDS primleri arasında oynaklık yayılımları olduğu ve küresel kriz döneminde CDS primlerinin oynaklık yayılımlarında artış olduğu belirlenmiştir. Fonseca ve Gottschalk (2020) 2007 - 2010 döneminde dört Asya - Pasifik ülkesi örnekleminde CDS primleriyle borsalar arasında oynaklık yayılımı olduğunu tespit etmişlerdir.

Yukarıdaki CDS ve borsa arasındaki oynaklık yayılımlarından farklı olarak bazı çalışmalarda bu değişkenler arasındaki ilişkiler araştırılmıştır. Belke ve Gokus (2011) 1 Ocak 2006 - 31 Aralık 2009 döneminde dört büyük $A B D$ bankası verileriyle yaptıkları çalışmada, kriz zamanlarında oynaklığın önemli derecede yükseldiği ve küresel kriz döneminde CDS primleriyle pay getirileri arasındaki negatif ilişkinin arttığı belirlenmiştir. Mateev ve Marinova (2017) Ocak 2008 - Ocak 2016 döneminde, 13 Avrupa ülkesinden 109 firma örnekleminde CDS primleriyle pay fiyatları arasındaki ilişkiyi araştırmışlar ve çalışmada CDS primleriyle pay fiyatları arasında uzun dönem ilişki olduğu görülmüştür.

Shahzad vd. (2019) 14 Aralık 2007 - 21 Eylül 2018 döneminde, ABD'de 11 sektöre ait pay piyasalarıyla bu sektörlerin CDS primleri arasındaki ilişkileri araştırmışlar ve pay piyasalarından CDS piyasalarına doğru tek yönlü nedensellik tespit edilmiştir. Bolaman Avcı (2020) 2003Q1 - $2018 Q 4$ dönemine ait verilerle Türkiye örnekleminde CDS primleriyle pay piyasaları arasındaki ilişkiyi araştırmıştır. Çalışmada, CDS primleriyle pay piyasası arasında uzun dönemli ilişkinin varlığı ve BiST100 getirilerinden CDS primlerine doğru tek yönlü nedensellik belirlenmiştir.

Shear ve Butt (2017) Aralık 2007 - Ekim 2016 döneminde 36 ülke verilerine dayanarak yukarıdaki çalışmalardan farklı olarak Panel VAR yöntemiyle yaptıkları çalışmada pay piyasalarında meydana gelen şokların CDS primleri üzerinde negatif etkiye sahip olduğu, pay piyasalarının CDS primlerindeki değişimleri açıkladığı, buna karşın CDS primlerinin pay piyasasına etkisinin az olduğu ve pay piyasasındaki değişimleri düşük düzeyde açıkladığı görülmüştür.

Borsalar ile faiz oranı arasındaki oynaklıkları esas alan çalışmalar ise Kasman vd. (2011), Liu ve Chen (2016), Lee ve Hsu (2016), Assefa, Esqueda ve Mollick (2017) ve Kurt Cihangir (2020) çalışmalarıdır. Kasman vd. (2011) 27 Temmuz 1999 - 9 Nisan 2009 döneminde, Türkiye'de 13 banka örnekleminde faiz oranı ve döviz kuru oynaklıklarının banka payları oynaklığına etkilerini araştırmışlardır. Çalışmada, faiz oranı oynaklıklarının banka pay oynaklıklarını pozitif yönde etkilediği ve aynı şekilde döviz kuru oynaklıklarının da banka pay oynaklıklarını artırdığı görülmüştür. Liu ve Chen (2016) Ocak 1985 - Mart 2009 döneminde Tayvan'da faiz oranlarıyla pay fiyatları arasındaki oynaklık yayılım ilişkisini incelemişlerdir. STVEC-GARCH yöntemi kullanılan 
çalışmada, pay fiyatlarıyla faiz oranları arasında uzun dönem ilişki olduğu, bir gecikme ile pay senetlerindeki oynaklığın cari dönemdeki faiz oranını etkilediği ve önceki dönem faiz oranlarııı önemli derecede cari dönem pay fiyatlarını etkilediği görülmüştür.

Lee ve Hsu (2016) G7 ekonomilerinde faiz oranı swapları ve pay piyasaları arasındaki oynaklığı araştırmışlardır. Sonuçlar, faiz oranı swap piyasaları arasında oynaklık yayılımı olduğunu, uzun dönemde swap piyasalarındaki oynaklık yayılım endeksinin pay piyasalarındaki oynaklığın sebebi olduğunu, uzun dönemde swap piyasaları oynaklık yayılım endeksinin pay piyasaları yayılımını etkilediğini göstermiştir. Assefa vd. (2017) Ocak 1999 - Aralık 2013 döneminde 21 gelişşş ve 19 gelişmekte olan ülke örnekleminde yaptıkları çalışmada faiz oranlarının hem gelişmiş ülkelerde hem de gelişmekte olan ülkelerde pay senetleri getirilerini olumsuz etkilediği görülmüştür. Kurt Cihangir (2020) Ağustos 2009 - Eylül 2018 dönemine ait veriler ve Türkiye örnekleminde CDS primlerine olan oynaklık yayılımlarını araştırmış ve faiz oranlarından CDS primlerine doğru oynaklık yayılımı görülmüştür.

Kar vd. (2016), Akkuş vd. (2018), Akardeniz ve Engin (2019) ile Taştan ve Güngör (2019) Türkiye örneğiyle araştırmalarını yapmışlardır. Kar vd. (2016) Eylül 2009 - Ekim 2015 dönemi ve Türkiye örnekleminde CDS primlerinin Euro/TL döviz kuru oynaklığına etkisini araştırmışlar ve MS VAR sonuçları ikinci rejimde CDS primlerinin döviz kuru oynaklığını artırdığını göstermiştir. Akkuş vd. (2018) 19 Mart 2012 - 24 Ekim 2017 dönemi, Türkiye örnekleminde, tahvil faiz oranlarıyla CDS primleri arasındaki oynaklık ilişkisi araştırmışlar ve faiz oranıyla CDS primleri arasında pozitif yönde oynaklık ilişkisi olduğunu tespit etmişlerdir. Taştan ve Güngör (2019) 1 Ocak 2001 - 4 Ocak 2019 döneminde, Türkiye'de pay senetleri oynaklığını etkileyen en önemli faktörün döviz kuru olduğunu, bunun yanında faiz oranı, CDS primleri, S\&P 500 endeksi oynaklığı ile BiST100 endeksi oynaklığı arasında pozitif ilişki bulunduğunu tespit etmişlerdir. Akardeniz ve Engin (2019) 2002 -2017 dönemine ait aylık veriler ve Türkiye örnekleminde, faiz kararlarının döviz oynaklığına etkisini araştırmışlar, genel olarak faiz oranından döviz kuruna doğru negatif yönde yayııım olduğu, dönemlere ayrıldığında ise bazen pozitif, bazen de negatif yönde oynaklık yayılımı olduğu anlaşılmıştır.

\section{Yöntem ve Veri}

Koşullu ve koşulsuz olmak üzere iki farklı oynaklık söz konusudur. Koşullu oynaklık modelinde piyasaya gelen bilgilere göre oynaklık modellemesi güncellenmektedir, koşulsuz oynaklıkta ise zaman içinde değişim söz konusu değildir (Mateev, 2019: 682). Değişen koşullu varyanslar ARCH modellerinde ifade edilmektedir. Engle (1982) tarafından geliştirilen Otoregresif Koşullu Değişen Varyans (ARCH) modeli aşağıdaki gibidir:

$$
\alpha_{t}^{2}=\alpha_{0}+\sum_{i=1}^{p} \alpha_{i} \varepsilon_{t-i}^{2}
$$

Bollerslev (1986), Otoregresif Koşullu Değişen Varyans (ARCH) modelinin geliştirerek Genelleştirilmiş Otoregresif Koşullu Değişen Varyans (GARCH) modeli haline getirmiştir:

$$
\alpha_{t}^{2}=\alpha_{0}+\sum_{i=1}^{p} \alpha_{i} \varepsilon_{t-i}^{2}+\sum_{j=i}^{q} \beta_{j} \sigma_{t-j}^{2}
$$

Burada;

$p \geq 0, \quad q>0$

$\alpha_{0}>0, \quad \alpha_{i} \geq 0 \quad i=1, \ldots . ., q$

$\beta_{\mathrm{j}} \geq 0 \quad i=1, \ldots ., q$

$\left(\alpha_{i}+\beta_{j}\right)<1$

olmalıdır. 
Bu denklemler neticesinden ortaya konulan ARCH etkisi kısa dönemde şokların kalıcılığını gösterirken, GARCH etkisi ise uzun dönemde şokların ısrarcılığını göstermektedir. ARCH piyasaya gelen haberlere verilen ani tepkileri, GARCH ise bir önceki dönem oynaklı̆̆ın cari döneme etkisini ölçmektedir.

Engle (2002) korelasyonların zaman içinde değişmesini ortaya koyan aşağıdaki dinamik koşullu korelasyon (DCC) modelini geliştirmiştir. DCC modelleri değişkenler arasındaki korelasyon ilişkilerini tahmin etmede yaygın olarak kullanılmaktadır.

$$
Q_{t}=S^{\mathrm{o}}(\dot{\mu}-\alpha-\beta)+A^{\mathrm{o}} \varepsilon_{t-1} \dot{\varepsilon}_{t-1}+\beta^{\mathrm{o}} Q_{t-1}
$$

Burada, $Q_{t}, \varepsilon_{t}^{\prime}$ nin zamanla değişen kovaryansını, $S^{0}$ ise $\alpha$ ve $\beta$ parametrelerinin negatif olmadığı hallerde $\varepsilon_{t}^{\prime}$ nin koşulsuz varyansıdır.

Hong (2001) koşullu değişen varyans sergileyen iki zaman serisi arasında oynaklık yayılımı için test istatistiği önermiştir. Test iki standart hata kareler arasındaki ağırlıklandırılmış çapraz korelasyonlara dayanmaktadır.

$$
Q_{1}=\left\{T \sum_{j=1}^{T-1} k^{2}\left(\frac{j}{M}\right) \rho_{u v}^{2}(j)-C_{1 T}(k)\right\} /\left\{2 D_{1 T}(k)\right\}^{1 / 2}
$$

$\mathrm{Q}_{1}$ istatistiği tek yönlü nedenselliği tespit etmek için kullanılmaktadır.

Hong'un (2001) test işlemleri şu şekilde özetlenebilir:

1. Hata terimleri için $\operatorname{GARCH}(p, q)$ modeli tahmin edilir.

2. Standardize hata kareler arasında çapraz korelasyon fonksiyonu $\rho_{u v}(j)$ hesaplanır.

3. Ağırıklandırılmış fonksiyon $K\left(\right.$.) ve tamsayı $M$ seçilir, $2 D_{1 T}(k)$ hesaplanır.

4. $Q_{1}$ istatistik değer hesaplanır ve uygun seviyedeki kritik değer ile karşılaştırılır. $Q_{1}$ kritik değerden büyükse $\mathrm{H}_{0}$ yokluk hipotezi reddedilir, aksi halde $\mathrm{H}_{0}$ reddedilmez.

Bu çalışmada, BIST 100 endeksi, ABD Doları (\$)/Türk Lirası (も) döviz kuru, gösterge niteliğindeki 2 yıllık devlet tahvil faizi ve Türkiye'nin 5 yıllık CDS primleri arasındaki oynaklık yayılımları ve oynaklık ilişkileri ile bu ilişkileri etkileyen ekonomik, politik ve sosyal etkenler araştırılmıştır. Çalışma dönemi 2 Ocak 2010 - 10 Nisan 2020 şeklindedir. Çalışma dönemi küresel finansal krizi kapsamaması için 2010 yılından başlatı Imıştır. Çalışma verileri, Türkiye Cumhuriyet Merkez Bankası (TCMB), Bloomberg ve investing.com'dan elde edilmiştir.

Tablo 1. Tanımlayıcı İstatistik

\begin{tabular}{|l|c|c|c|c|}
\hline & BiST100 & KUR & FAiz & CDS \\
\hline Ortalama & 0,023226 & 0,059271 & 0,011548 & 0,032932 \\
\hline En Büyük & 6,895168 & 14,70657 & 21,18163 & 27,37838 \\
\hline En Küçük & $-11,06379$ & $-6,475749$ & $-18,92420$ & $-35,89723$ \\
\hline Std. Sapma & 1,432741 & 0,835917 & 1,915257 & 3,101407 \\
\hline Çarpıklık & $-0,597050$ & 2,605171 & 0,865298 & 0,015405 \\
\hline Basıklık & 6,804755 & 50,61781 & 25,33773 & 17,90416 \\
\hline Jarque-Bera & $1688,929^{* * *}$ & $243706,0^{* * *}$ & $53313,33^{* * *}$ & $23592,59^{* * *}$ \\
\hline Gözlem Sayısı & 2549 & 2549 & 2549 & 2549 \\
\hline
\end{tabular}

*** işareti \%1 düzeyinde anlamlılı̆̆ göstermektedir.

Değişkenlere ait günlük serilerden $r_{t}=100 * \operatorname{Ln}\left(P_{t} / P_{t-1}\right)$ formülüyle getiriler elde edilmiş ve çalışmada bu getiri serileri kullanılmışır. Getiri serilerine ilişkin özet istatistik Tablo 1'de görülmektedir. Örneklem döneminde değişkenlerin ortalama getirileri pozitiftir. En yüksek standart sapma CDS primlerinde 
görülmektedir. Faizin standart sapması yani riski BisT 100 ve döviz kurundan yüksek olmasına rağmen getirisi bu iki değişkenden daha düşüktür. Normal dağılımda çarpıklığın sıfıra (0) ve basıklığın üçe (3) yakın olması beklenmektedir. Tablo 1'de görüldü üzere özellikle basıklık değerleri oldukça yüksektir. Bu durum finansal zaman serilerinin temel özelliğidir. Normal verilerde gözlem sayısını artırarak ortalamaya doğru yaklaşıııken finansal zaman serilerinde ise ortalamadan uzaklaşılmaktadır.

\section{Bulgular}

Değişkenlere ait korelasyon katsayıları ve birim kök testleri Tablo 2'de görülmektedir. BísT 100 ile döviz kuru arasındaki katsayılar hariç diğer değişkenler arasındaki korelasyon katsayıları anlamlıdır. BiST 100 ile faiz ve CDS primleri arasındaki korelasyon katsayısı negatif; döviz kuru ile faiz ve CDS primleri arasındaki katsayı ve faiz ile CDS primleri arasındaki katsayı pozitiftir. Augmented Dickey-Fuller (ADF) ve Phillips-Perron (PP) birim kök test sonuçları getiri serilerinin düzeyde durağan olduklarını göstermektedir.

Tablo 1. Korelasyon Katsayıları ve Birim Kök Testleri

\begin{tabular}{|l|c|c|c|c|}
\hline & BIST100 & KUR & FAiZ & CDS \\
\hline BisT100 & 1 & & & \\
\hline KUR & $-0,006256$ & 1 & & \\
\hline FAiz & $-0,364613^{* * *}$ & $0,136690^{* * *}$ & 1 & \\
\hline CDS & $-0,500344 * * *$ & $0,092502 * * *$ & $0,366401^{* * *}$ & 1 \\
\hline ADF & $-24,6297^{* * *}$ & $-25,5505^{* * *}$ & $-16,1827^{* * *}$ & $-19,6801 * * *$ \\
\hline PP & $-50,0377^{* * *}$ & $-44,2361^{* * *}$ & $-57,0390^{* * *}$ & $-41,0351^{* * *}$ \\
\hline
\end{tabular}

*** işareti \%1 düzeyinde anlamlılı̆̆ı göstermektedir.

Şekil 1. Getiri ve Koşullu Varyans Grafikleri
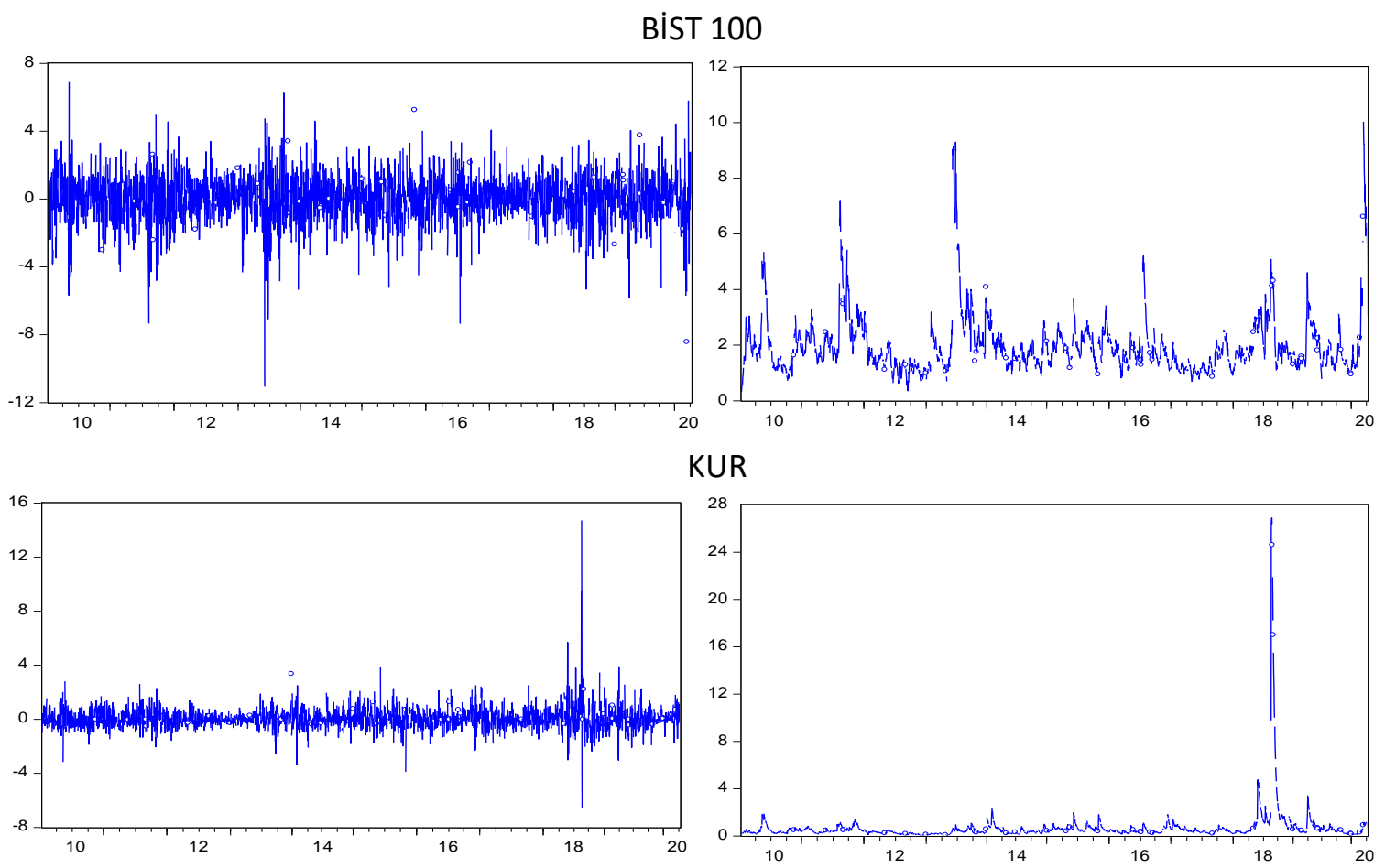
Şekil 1. Getiri ve Koşullu Varyans Grafikleri (Devamı)

FAiz
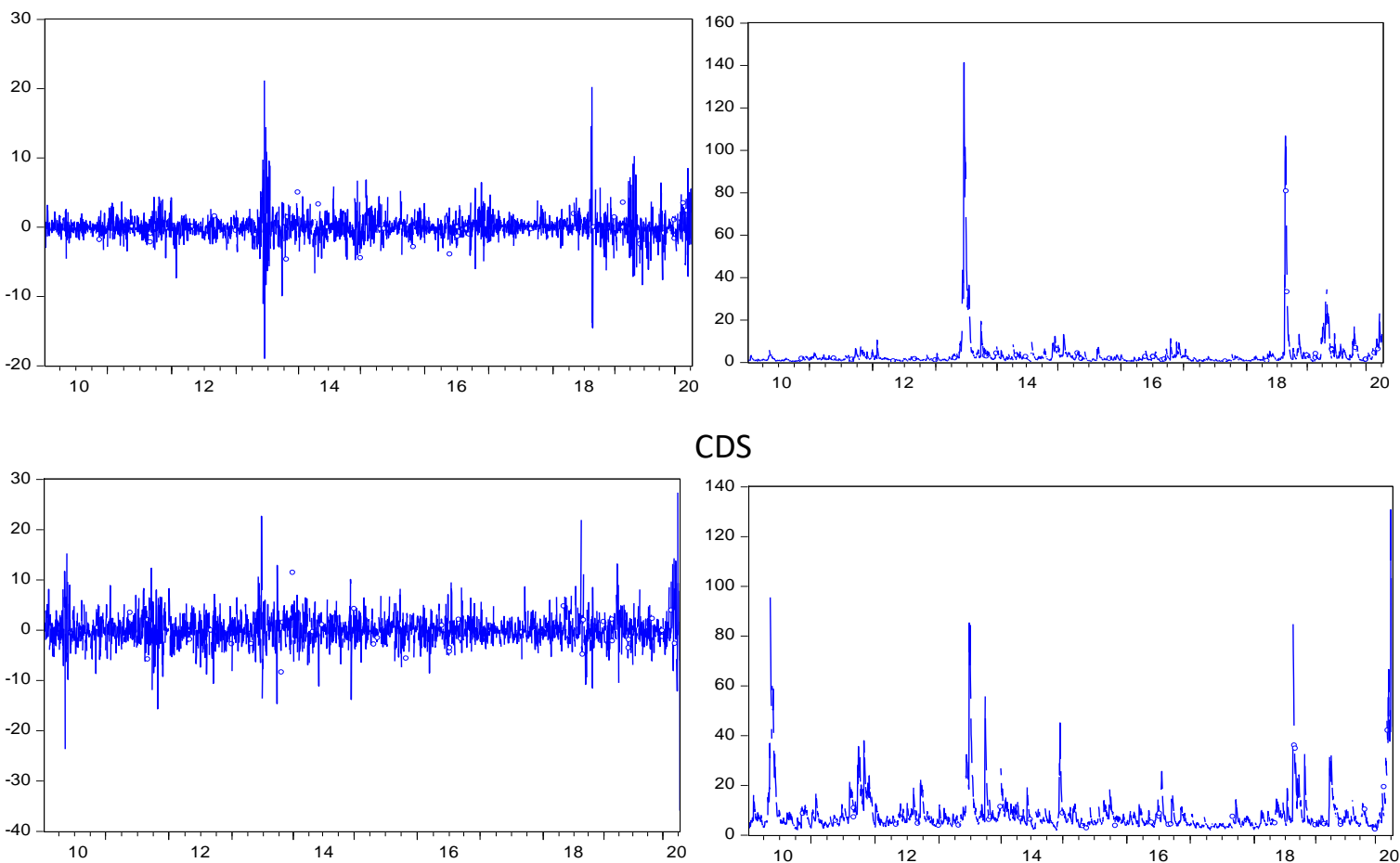

Şekil 1'de getiri serilerinden ortaya çıkan oynaklıklar ve serilere ait $\operatorname{GARCH}(1,1)$ modelinden elde edilen koşullu varyans grafikleri görülmektedir. Oynaklık kümelenmelerine bakıldığında BíST 100 endeks oynaklığııın ilk sırada, daha sonra ise CDS primleri oynaklığı görülmektedir. Oynaklıklarının boyutlarına bakıldığında ise en yüksek oynaklık boyutuyla döviz kuru (KUR) ilk sırada, daha sonra ise faiz ve CDS primleri sıralanmaktadır. Döviz kurunda (KUR) gerçekleşen oynaklık 2018 yılında tek seferde ve yüksek düzeyde oluşmuştur. Oysa, Tablo 1'de görüldüğü üzere döviz kurunun (KUR) tüm örnekleme yayılan oynaklığı faiz ve CDS primleri oynaklıklarından daha düşük düzeydedir. Serilerin koşullu varyansları dönem dönem yüksek değişkenlikler göstermiştir. BIST 100, 2013 ve 2020 yıllarında, döviz kuru (KUR) 2018 yaz aylarında, faiz 2013 ve 2018 yaz aylarında, CDS primleri ise 2010, 2013, 2018 ve 2020 yıllarında koşullu varyanslarda büyük artışlar sergilemişlerdir.

Tablo 3'de GARCH $(1,1)$ modeline ait tahmin sonuçları görülmektedir. Veriler normal dağılım özelliği sergilemediğinden dolayı genelleştirilmiş hata dağılımına (GED) göre tahmin yapılmıştır. Bütün modellerde $\operatorname{ARCH}(\alpha)$ ve GARCH $(\beta)$ parametrelerinin anlamlı oldukları görülmektedir. ARCH $(\alpha)$ etkisi kısa dönemde şokların şiddetini gösterirken, GARCH etkisi ise şokların uzun dönemde kalıcılı̆ını göstermektedir. Dolayısıyla, BIST 100, döviz kuru, CDS primleri ve faiz oranlarındaki oynaklıkların kısa dönemde şiddetli ve uzun dönemde ısrarcı olduğu söylenebilir.

En yüksek ARCH parametresi faizde, en yüksek GARCH parametresi ise BiST'te görülmektedir. Diğer değişkenlere göre en büyük şoklar faizde, şokların kalıcılığı ise BiST 100'de olduğu anlaşılmaktadır. Varyans denklemlerine değişkenlerin oynaklıkları eklenerek, çalışmada kullanılan değişkenlere ilişkin oynaklıkların, birbirlerinin oynaklıklarına olan etkilerine bakılmıştır. Buna göre; BIST 100'deki oynaklığı sadece CDS primlerindeki oynaklığın etkilediği, döviz kurundaki (KUR) oynaklığı CDS primlerindeki oynaklığın etkilediği, faizdeki oynaklığı döviz kurundaki (KUR) oynaklığın etkilediği ve CDS primlerindeki oynaklığı ise BiST 100' deki oynaklığın etkilediği görülmektedir. 
Tablo 3. GARCH $(1,1)$ Model Tahmin Sonuçları

\begin{tabular}{|c|c|c|c|c|}
\hline Değişkenler & BisT100 & KUR & FAiz & CDS \\
\hline \multicolumn{5}{|c|}{ Ortalama denklemi } \\
\hline Sabit & 0.101627 & 0.007991 & -0.022994 & $-0.124408^{*}$ \\
\hline AR (1) & 0.323328 & $0.938801^{*}$ & $-0.623895^{* *}$ & 1.192297* \\
\hline AR (2) & -0.817143 & - & -0.327109 & $-0.567987^{*}$ \\
\hline$A R(3)$ & 0.263743 & - & $0.787448^{*}$ & 0.995569* \\
\hline AR (4) & -0.039955 & - & $0.536880 * * *$ & $-0.817688^{*}$ \\
\hline$A R(5)$ & -0.012469 & - & $0.472670 * *$ & $-0.051220 * *$ \\
\hline MA (1) & -0.321531 & $-0.860149 *$ & $0.617173 * *$ & $-1.032988^{*}$ \\
\hline MA (2) & 0.832541 & $-0.075146^{*}$ & 0.356656 & $0.381317^{*}$ \\
\hline MA (3) & -0.265244 & -0.001378 & $-0.765415^{*}$ & $-0.900053^{*}$ \\
\hline $\mathrm{MA}(4)$ & 0.054227 & 0.006022 & $-0.506907 * * *$ & $0.627205^{*}$ \\
\hline MA (5) & - & - & $-0.488198 *$ & $0.214537^{*}$ \\
\hline \multicolumn{5}{|c|}{ Varyans Denklemi } \\
\hline Sabit & $0,082888 * * *$ & $0,012711^{* * *}$ & $0,121767 * * *$ & $0,511402^{* * *}$ \\
\hline$\alpha$ & $0,046409 * * *$ & $0,091226 * * *$ & $0,174123 * * *$ & $0,129922 * * *$ \\
\hline$\beta$ & $0,909863 * * *$ & $0,887955 * * *$ & $0,790563 * * *$ & $0,812739 * * *$ \\
\hline BisT100 & - & $-0,007000$ & $-7,36 \mathrm{E}-05$ & $-0,280222 * * *$ \\
\hline KUR & 0,017897 & - & $0,174495 * * *$ & 0,136250 \\
\hline FAiz & 0,005772 & 0,004833 & - & 0,020634 \\
\hline CDS & $0,044338 * * *$ & $0,004685^{* *}$ & 0,012966 & - \\
\hline $\operatorname{LM}(50)$ & 52,142 & 59,697 & 53,593 & 34,015 \\
\hline $\mathrm{Q}(50)$ & 54,136 & 35,767 & 72,390 & 49,934 \\
\hline GED & $1,376024 * * *$ & $1,288645^{* * *}$ & $1,025989 * * *$ & $1,114443^{* * *}$ \\
\hline
\end{tabular}

Not: ${ }^{*}, * *$ ve $* * *$ işaretleri \%1, \%5 ve \%10 önem düzeyini göstermektedir.

Tablo 4. Hong (2001) Varyansta Nedensellik Testi Sonuçları

\begin{tabular}{|c|c|c|c|c|c|c|}
\hline \multirow{2}{*}{$\begin{array}{l}\text { Gecikme } \\
\text { Uzunluğu }\end{array}$} & \multicolumn{2}{|c|}{$\begin{array}{c}\text { BisT - KUR íLişKisi } \\
\text { (Q İstatistik) }\end{array}$} & \multicolumn{2}{|c|}{$\begin{array}{c}\text { BisT - FAiz íişKisi } \\
\text { (Q İstatistik) }\end{array}$} & \multicolumn{2}{|c|}{$\begin{array}{c}\text { BiST - CDS íLişKisi } \\
\text { (Q İstatistik) }\end{array}$} \\
\hline & BIST $\rightarrow$ KUR & KUR $\rightarrow$ BiST & BisT $\rightarrow$ FAiZ & FAiZ $\rightarrow$ BisT & BisT $\rightarrow$ CDS & $\mathrm{CDS} \rightarrow \mathrm{BIST}$ \\
\hline 1 & $139,577^{* * *}$ & $-0,443$ & $-0,512$ & $-0,621$ & 0,323 & $-0,686$ \\
\hline 2 & $135,661^{* * *}$ & $2,240 * *$ & $-0,630$ & $-0,492$ & 0,327 & $-0,803$ \\
\hline 3 & $127,249 * * *$ & $3,975^{* * *}$ & $-0,699$ & $-0,234$ & 0,261 & $-0,807$ \\
\hline 4 & $119,037^{* * *}$ & $4,732 * * *$ & $-0,756$ & 0,028 & 0,147 & $-0,519$ \\
\hline 5 & $111,824^{* * *}$ & $5,034 * * *$ & $-0,826$ & 0,228 & 0,074 & $-0,140$ \\
\hline \multirow{2}{*}{$\begin{array}{l}\text { Gecikme } \\
\text { Uzunluğu }\end{array}$} & \multicolumn{2}{|c|}{$\begin{array}{c}\text { KUR - FAiz íLişKisi } \\
\text { (Q İstatistik) }\end{array}$} & \multicolumn{2}{|c|}{$\begin{array}{c}\text { KUR - CDS íLişKisi } \\
\text { (Q İstatistik) }\end{array}$} & \multicolumn{2}{|c|}{$\begin{array}{c}\text { FAiz - CDS íLişKisi } \\
\text { (Q İstatistik) }\end{array}$} \\
\hline & KUR $\rightarrow$ FAiZ & FAiZ $\rightarrow$ KUR & $\mathrm{KUR} \rightarrow \mathrm{CDS}$ & $\mathrm{CDS} \rightarrow \mathrm{KUR}$ & FAiZ $\rightarrow$ CDS & $\mathrm{CDS} \rightarrow \mathrm{FAiZ}$ \\
\hline 1 & $2,354^{* * *}$ & $254,261^{* * *}$ & $-0,699$ & $128,922^{* * *}$ & $5,549 * * *$ & $-0,328$ \\
\hline 2 & $3,938 * * *$ & $249,317^{* * *}$ & $-0,305$ & $126,646^{* * *}$ & $5,214 * * *$ & 0,744 \\
\hline 3 & $4,961 * * *$ & $235,562 * * *$ & $-0,085$ & $119,842 * * *$ & $4,692^{* * *}$ & $1,461^{*}$ \\
\hline 4 & $5,365 * * *$ & $221,405^{* * *}$ & $-0,028$ & $112,730 * * *$ & $4,217^{* * *}$ & $1,756 * *$ \\
\hline 5 & $5,444 * * *$ & $208,644^{* * *}$ & $-0,044$ & $106,312^{* * *}$ & $3,813^{* * *}$ & $1,839 * *$ \\
\hline
\end{tabular}

Tablo 4'de varyansta nedensellik sonuçları görülmektedir. Buna göre, BiST 100 - döviz kuru (KUR), döviz kuru (KUR) - faiz ve faiz - CDS primleri arasında karşılıklı oynaklık yayılımı, döviz kuru (KUR) - CDS primleri arasında tek yönlü ve CDS primlerinden döviz kuruna (KUR) doğru oynaklık yayılımı söz konusudur. Değişkenler arasında en çok oynaklık alan döviz kurudur (KUR). Döviz kuru, BiST 100, faiz ve CDS primlerinden oynaklık yayılımı almaktadır. Bu durum, döviz kurunun (KUR) hassas ve riskli bir varlık olduğunu ortaya koymaktadır. En az oynaklık yayılımı alan değişkenlerin BIST 100 ve CDS primleri olduğu anlaşılmaktadır. Döviz kuru (KUR) net oynaklık alıcısıdır. Net oynaklık yayıcısı yoktur. Değişkenler arasında, döviz kuru (KUR), faiz ve 
CDS primlerinin BiST 100'e göre daha fazla oynaklık yaydığı anlaşılmaktadır. Döviz kuru (KUR), faiz ve CDS primlerinin iki değişkene oynaklık yaydığı, buna karşılık BiST 100'ün sadece bir değişkene (KUR) oynaklık yaydığı görülmektedir.

Tablo 5. DCC GARCH Model Sonuçları ${ }^{1}$ (Engle, 2002)

\begin{tabular}{|l|c|c|c|c|}
\hline & Katsayılar & Std. Hatalar & T istatistik & T-Olasilık \\
\hline$\alpha$ & 0,006227 & 0,0027794 & 2,240 & 0,0252 \\
\hline$\beta$ & 0,976286 & 0,015207 & 64,20 & 0,0000 \\
\hline Rho_KUR_BiST & $-0,016700$ & 0,025064 & $-0,6663$ & 0,5053 \\
\hline Rho_FAiZ_BiST & $-0,366515$ & 0,023798 & $-15,40$ & 0,0000 \\
\hline Rho_CDS_BiST & $-0,478757$ & 0,020921 & $-22,88$ & 0,0000 \\
\hline Rho_FAiZ_KUR & 0,016062 & 0,026010 & 0,6175 & 0,5369 \\
\hline Rho_CDS_KUR & 0,057401 & 0,025737 & 2,230 & 0,0258 \\
\hline Rho_CDS_FAiZ & 0,393540 & 0,023104 & 17,03 & 0,0000 \\
\hline
\end{tabular}

Tablo 5'de ve Şekil 2'de değişkenler arası ilişkiler görülmektedir. BiST 100'ün faiz ve CDS primleriyle negatif yönde bir ilişkisi görülmektedir. Risk ve maliyet göstergesi olarak faiz ve CDS primlerinin BiST 100 ile negatif yönde ilişkili olması beklentiyle uyumludur. CDS primlerinin faiz ve kur ile pozitif yönde ilişkisi görülmektedir. illişkinin katsayılarına bakıldığında CDS primleri - faiz ilişkisinin CDS primleri - döviz kuru ilişkisinden daha yüksek olduğu anlaşılmaktadır. Dinamik koşullu korelasyon sonuçlarına göre, değişkenlerle anlamlı ilişkisi en yüksek değişken CDS primleridir. Bu, CDS primlerinin piyasalardaki önemini göstermektedir.

Bu çalışmada olduğu gibi literatürde borsalar ile CDS primleri arasında oynaklık ilişkisi görülen çalışmalar, I (2015), Castellano ve Scaccia (2014), Belke ve Gokus (2011), Fonseca ve Wang (2016), ve Balcılar vd. (2018) şeklindedir. BiST 100 ile döviz kuru (KUR) arasındaki oynaklık yayılım sonuçları ise MoralesZumaquero ve Sosvilla-Rivero (2018) ile Yaman ve Korkmaz (2020) çalışmalarıyla benzerlikler taşımaktadır. BiST 100 ve faiz oranı arasındaki sonuçlar Liu ve Chen (2016), Lee ve Hsu (2016) ve Assefa vd. (2017) çalışmalarıyla benzerlikler göstermektedir. Faiz oranı ve CDS primleri arasında ortaya çıkan sonuçlar ise Akkuş vd. (2018) ve Kurt Cihangir (2020) çalışma sonuçlarıyla benzer özellikler taşımaktadır.

Şekil 2. Değişkenler Arasındaki Dinamik Koşullu Korelasyonlar

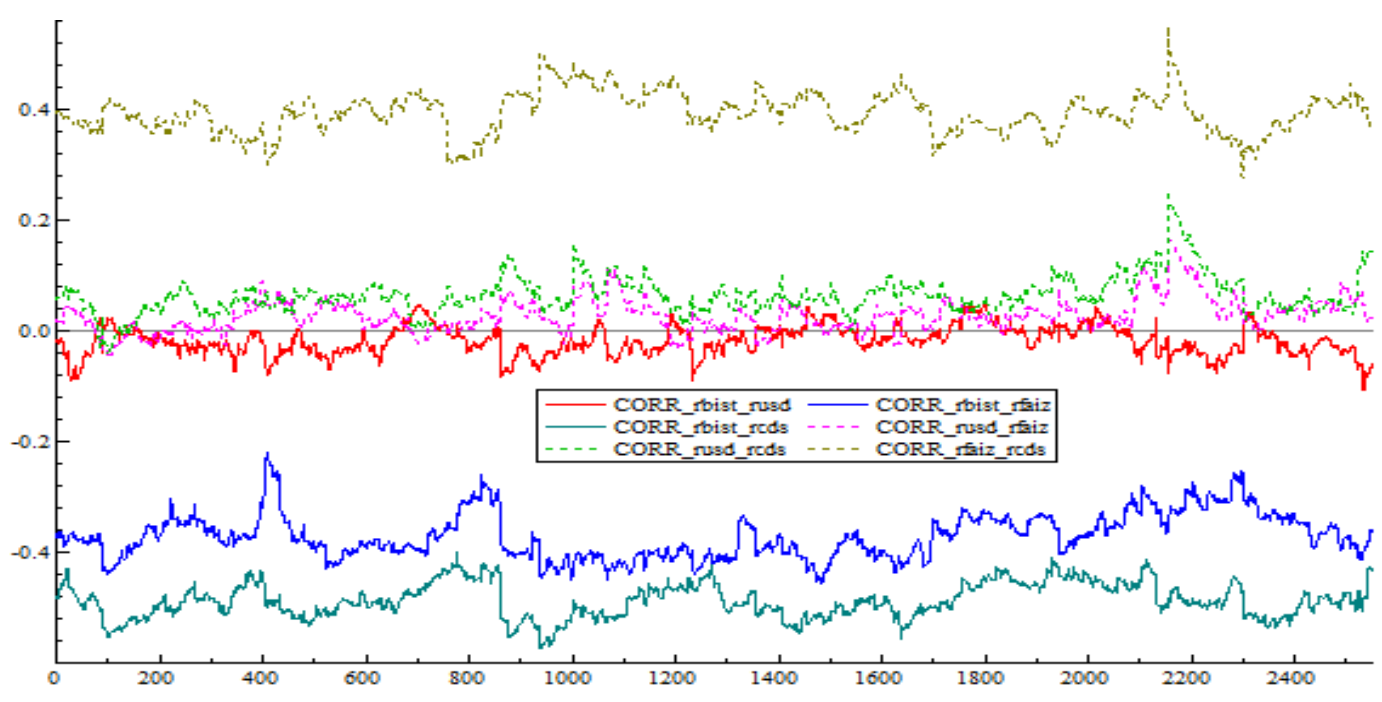

Şekil 2'de görüldüğü üzere değişkenler arası korelasyonların düzeyi zamana göre değişiklik göstermektedir. 2011 yılı yaz ayları (400), 2013 yılı yaz ayları (800) 2018 yılı yaz aylarında (2.100) değişkenler arası korelasyonlarda önemli sayılabilecek farklılıklar görülmektedir. Söz konusu korelasyonların ekonomik, politik ve sosyal olaylar tarafından etkilendiği değerlendirilerek örneklem dönemi olan 2 Ocak 2010 - 10 Nisan 
2020 tarihleri arasındaki politik, ekonomik ve sosyal olaylar Tablo 6'daki gibi belirlenmiştir. Ekonomik, politik ve sosyal olayların değerleri kukla değişken olarak tanımlanmış ve dinamik koşullu korelasyon analiz sonuçları anlamlı çıkan faiz - BiST 100, CDS primleri - BIST 100, CDS primleri - kur ve CDS primleri - faiz arasındaki korelasyonlara etkileri araştırılmıştır.

Tablo 2. Ekonomik, Politik ve Sosyal Olaylar

\begin{tabular}{|c|l|c|c|}
\hline Sıra & Olaylar & Kısaltmalar & Başlama ve Bitiş \\
\hline 1 & 24. Dönem Milletvekili Seçimleri & MLTV_24 & $14.03 .2011-17.06 .2011$ \\
\hline 2 & 25. Dönem Milletvekilliği Seçimleri & MLTV_25 & $10.03 .2015-12.06 .2015$ \\
\hline 3 & Mahalli İdareler Genel Seçimleri & MHLI_2014 & $01.01 .2014-04.04 .2014$ \\
\hline 4 & Anayasa Değişikliği & ANAYS & $16.02 .2017-21.04 .2017$ \\
\hline 5 & Zeytin Dalı Harekatı ${ }^{2}$ & ZYTNDL & $20.01 .2018-13.03 .2018$ \\
\hline 6 & 2018 Döviz Kur Dalgalanması & KUR_2018 & $1.7 .2018-1.11 .2018$ \\
\hline 7 & Mahalli İdareler Genel Seçimleri & MHLı_2019 & $01.01 .2019-05.04 .2019$ \\
\hline 8 & Gezi Parkı Olayları & GEZI & $27.05 .2013-26.09 .2013$ \\
\hline 9 & Cumhurbaşkanlığı Seçimi & CMHR & $29.06 .2014-15.08 .2014$ \\
\hline 10 & 26. Dönem Milletvekilliği Seçimleri & MLTV_26 & $31.08 .2015-6.11 .2015$ \\
\hline 11 & 15 Temmuz Darbe Girişimi & TMZ_15 & $15.07 .2016-16.08 .2016$ \\
\hline 12 & Cumhurbaşkanlığı ve M.V. Seçimi & CMHR_MLTV & $30.04 .2018-29.06 .2018$ \\
\hline 13 & Barış Pınarı Harekatı & BRSPNR & $9.10 .2019-25.11 .2019$ \\
\hline 14 & COVID-19 Salgını & CVD19 & $31.12 .2019-$ Devam ediyor \\
\hline
\end{tabular}

Kaynak: Yüksek Seçim Kurulu (YSK) ve gazeteler

Not: Ekonomik, politik ve sosyal olaylarla ilgili tarihlerin belirlenmesi: Milletvekilliği, mahalli idareler, anayasa değişikliği, cumhurbaşkanlı̆̆ı seçimlerinde YSK tarafından yayımlanan seçim takvimi; yurt dışı askeri hareketlerde, hareketin fiilen başlama ve bitiş tarihleri; Gezi Parkı olaylarında, olayların başlama ve bitiş tarihleri; 15 Temmuz darbe girişiminde, darbenin fiilen başlaması ve bastıııma tarihleri, COVID-19 salgını başlangıç tarihi ise Dünya Sağlık Örgütü (WHO) tarafından ilan edilen tarihi göstermektedir.

Regresyon tahmininde kullanılan en yaygın yöntem En Küçük Kareler (EKK) yöntemidir. EKK yöntemi hata terimlerinin normal dağıımına dayanmaktadır. Verilerin klasik varsayımları sağlamadığı durumlar için robust (dayanıklı) regresyon tahmincileri önerilmiştir (Öztürk ve Türkay, 2005: 264). Tablo 7'de dayanıklı EKK yöntemine göre yapılmış regresyon sonuçları görülmektedir. Bu sonuçlara göre, ekonomik, politik ve sosyal olayların faiz - BIST 100, CDS primleri - BIST 100, CDS primleri - döviz kuru ve CDS primleri - faiz arasındaki korelasyonları etkilediği anlaşılmaktadır. Özellikle 2014 ve 2019 mahalli seçimleri, 2017 yılı Anayasa değişikliği, Gezi Parkı olayları, 15 Temmuz 2016 darbe girişimi ve 2018 yılı Cumhurbaşkanlığı ve Milletvekilliği seçimlerinin değişkenler arasındaki tüm korelasyonları etkilediği anlaşılmaktadır. Dolayısıyla, BiST 100, döviz kuru, faiz oranı ve CDS primleri arasındaki korelasyonların ekonomik, politik ve sosyal olaylara bağlı olarak değiştiği söylenebilir. Ortaya çıkan bu sonuçlar literatürdeki Hurduzeu vd. (2015) ve Balcılar vd. (2018) çalışmalarına benzerlikler göstermektedir.

Yapılan analizlere genel olarak bakıldığında aşağıdaki şu değerlendirmeler yapılabilir: BiST 100, döviz kuru, faiz ve CDS primleri arasındaki oynaklıklar, oynaklık yayılımları ve oynaklık ilişkilerinde CDS primlerinin diğer değişkenlere göre ön plana çıktığı anlaşımaktadır. GARCH modellerinde diğer değişkenleri en fazla etkileyen değişken CDS primleridir. Oynaklık yayılımlarında, diğer değişkenlere en fazla yayılımı olan CDS primleridir. Oynaklık ilişkilerinde ise daha fazla değişkenle anlamlı oynaklık ilişkisi olan CDS primleridir. Elde edilen sonuçlar teori ve beklentilerle genel olarak uyumludur. Ortaya çıkan bu sonuçlara göre, CDS primleri yatırımcılar, portföy yöneticileri, risk yöneticileri ve ekonomi yönetimleri açısından önemli bir göstergedir. Oynaklık ilişkilerinde, BIST 100'ün faiz ve CDS primleriyle olan ilişkileri negatif yönlü, CDS primlerinin kur ve faiz ile olan ilişkisi pozitif yönlüdür. Oynaklık yayılımlarında ise, BiST 100 - kur, kur - faiz ve faiz - CDS primleri arasında karşııklı, CDS primlerinden döviz kuruna doğru tek yönlü oynaklık yayııımı belirlenmiştir. Bu sonuçlar genel olarak teori ve beklentilerle uyumludur. Faiz - BiST 100, CDS primleri - BIST 100, CDS primleri - kur ve 
CDS primleri - faiz arasındaki dinamik korelasyon ilişkilerini ekonomik, politik ve sosyal olayların etkilediği anlaşılmaktadır.

Tablo 7. Ekonomik, Politik ve Sosyal Olayların Değişkenler Arası Ilişkilere Etkisi, Dayanıklı EKK Yöntemi

\begin{tabular}{|c|c|c|c|c|}
\hline Değişkenler & Faiz - BiST & CDS - BisT & CDS - KUR & CDS - Faiz \\
\hline MLTV_24 & $0,004[0,98]$ & $0,005[1,29]$ & $-0,012[-3,99]^{* * *}$ & $-0,043\{-11,08]^{* * *}$ \\
\hline MLTV_25 & $-0,002[-0,45]$ & $-0,006[-1,53]$ & $-0,004[-1,45]$ & $0,007[1,80]^{*}$ \\
\hline MHLI_2014 & $-0,031[-6,90]^{* * *}$ & $-0,020[-5,15]^{* * *}$ & $0,035[11,09]^{* * *}$ & $0,058[14,33]^{* * *}$ \\
\hline ANAYS & $0,041[7,74]^{* * *}$ & $0,041[8,82]^{* * *}$ & $-0,016[-4,44]^{* * *}$ & $-0,0254[-5,38]^{* * *}$ \\
\hline ZYTNDL & $0,027[4,67]^{* * *}$ & $0,026[5,06]^{* * *}$ & $0,018[4,35]^{* * *}$ & $-0,0008[-0,15]$ \\
\hline KUR_2018 & $0,055[13,45]^{* * *}$ & $0,004[1,22]$ & $0,099[34,36]^{* * *}$ & $0,033[9,08]^{* * *}$ \\
\hline MHLI_2019 & $0,083[18,53]^{* * *}$ & $0,010[2,50]^{* *}$ & $0,017[5,57]^{* * *}$ & $-0,050[-12,56]^{* * *}$ \\
\hline MLTV_26 & $-0,032[-5,74]^{* * *}$ & $-0,044[-10,15]^{* * *}$ & $-0,003[-0,90]$ & $0,028[5,59]^{* * *}$ \\
\hline GEZI & $-0,025[-5,92]^{* * *}$ & $-0,045[-13,78]^{* * *}$ & $0,034[12,49]^{* * *}$ & $0,032[8,63]^{* * *}$ \\
\hline CMHR & $-0,037[-5,36]^{* * *}$ & $0,007[1,38]$ & $0,030[6,73]$ & $0,029[4,67]^{* * *}$ \\
\hline TMZ_15 & $-0,047[-5,84]^{* * *}$ & $-0,050[-8,07]^{* * *}$ & $0,019[3,68]^{* * *}$ & $0,057[8,01]^{* * *}$ \\
\hline CMHR_MLTV & $0,063[10,41]^{* * *}$ & $0,043[9,20]^{* * *}$ & $0,057[14,53]^{* * *}$ & $0,033[6,19]^{* * *}$ \\
\hline BRSPNR & $-0,002[-0,37]$ & $-0,004[-0,91]$ & $-0,017[-3,82]^{* * *}$ & $0,026[4,30]^{* * *}$ \\
\hline CVD19 & $-0,014[-3,11]^{* * *}$ & $0,004[1,29]$ & $0,002[0,89]$ & $0,024[5,69]^{* * *}$ \\
\hline \multicolumn{5}{|c|}{$r^{2}=0,103$ Düzeltilmiş $r^{2}=0,101 \quad$ Olasılık= 0,000000 Bilgi Kriterleri= 3,176 (Akaike), 3,225 (Schwarz) } \\
\hline
\end{tabular}

Oynaklık ilişkilerinin ve oynaklık yayılımlarının görülmesi, Türkiye'de bu finansal varlıklarla portföy yönetimi yapmak isteyenler açısından bazı sonuçlar ortaya çıkarmaktadır. Oynaklık yayılımlarının ve bu yayılım yönlerinin tespit edilmesi varlık fiyatlarının keşfi, fiyat tayini, finansal varlık fiyatlarının belirleyicileri gibi durumlar açısından imkanlar sağlamaktadır. Finansal varlık oynaklıkları arasındaki ilişkiler ve bu ilişkilerin katsayısı ise çeşitlendirme ile portföy riskini yönetme bakımından önemli sonuçlar doğurmaktadır.

Döviz kurunda oluşan şoklar BIST 100'deki şokları etkilemiştir. Faiz ve CDS primlerindeki oynaklıklar ile BiST 100'deki oynaklıklar arasında negatif yönde ilişki belirlenmiştir. Buna göre, pay piyasası yatırımcıları, yatırımlarında döviz kuru, faiz ve CDS primlerindeki hareketlere dikkat ederek portföy güncellemeleri yapabilirler. Finansal varlıklar arasındaki negatif oynaklık ilişkileri dikkate alınarak portföy riskleri azaltılabilir.

Genel olarak stres dönemlerinde piyasalar arası ilişkiler artmaktadır. Ekonomik, politik ve sosyal olayların piyasalar arası ilişkileri etkilemesi "stres dönemlerinde piyasalar arası ilişkiler artar" hipotezini doğrular niteliktedir. Burada politik, ekonomik ve sosyal olayların risk faktörlerini yükselttiği dönemlerde BiST 100, döviz kuru, faiz oranı ve CDS primleri arasındaki dinamik koşullu korelasyonlar da artmıştır.

\section{Sonuç}

Finansal piyasalarda görülen oynaklıklar son yıllarda, özellikle 2008 küresel finansal kriz sonrasında artışlar göstermiştir. Oynaklıkların artmasına sebep olan temel etken risk algısının gittikçe artmasıdır. 2008 küresel kriz sonrasında Avrupa'da yaşanan borç krizi, ABD - Çin arasında yaşanan ticari çekişmeler, Ortadoğu ve diğer bölgelerdeki gelişmeler risk algısını artırmıştır. Bunların yanında, finansal piyasalarda katıımcıların artması, yapılandırımış ürünler gibi finansal araç ve tekniklerin gelişmesi, teknolojik değişim, iletişim araçlarının gelişmesi, küresel rekabet, ekonomik durgunluk ve düşük toparlanma gibi süreçler finansal piyasalardaki oynaklıkları önemli derecede etkilemiştir.

Finansal varlık fiyat oynaklıklarını tespit ve tahmin etmek, oynaklıkları modellemek, varlıklar arasında görülen oynaklık yayılımlarını ve bu yayılımların yönlerini ortaya koymak, varlıklar arasındaki oynaklık ilişkilerinin katsayılarını belirlemek portföy yönetimi açısından kullanılabilir önemli bilgilerdir. Bu çalışmada, Türkiye'de, 2 Ocak 2010 - 10 Nisan 2020 döneminde günlük veriler kullanılarak BisT 100 endeksi, döviz kuru (\$/€), gösterge niteliğindeki 2 yıllık devlet tahvil faizi ve Türkiye'nin 5 yıllık CDS primleri arasındaki oynaklık ilişkileri ve oynaklık yayılımlarıyla bu oynaklık ilişkilerini etkileyen ekonomik, politik ve sosyal faktörler tespit 
edilmeye çalışımıştır. Çalışmada değişkenler arasında oynaklık yayılımları ortaya çıkmıştır. BíST 100 endeksi - döviz kuru, faiz - döviz kuru ve faiz - CDS primleri arasında karşılıklı oynaklık yayılımları ve CDS primlerinden döviz kuruna doğru tek yönlü oynaklık yayılımı olduğu anlaşıımıştır. Oynaklık ilişkilerine bakıldığında ise faiz BIST 100 endeksi ve CDS primleri - BIST 100 endeksi arasında negatif oynaklık ilişkisi olduğu, buna karşın CDS primleri - faiz ve CDS primleri - döviz kuru arasında pozitif oynaklık ilişkisi görülmüştür. Çalışmada ayrıca, faiz - BIST 100, CDS primleri - BIST 100, CDS primleri - döviz kuru ve CDS primleri - faiz arasındaki dinamik koşullu korelasyonları özellikle politik olaylar başta olmak üzere ekonomik ve sosyal faktörlerin etkilediği anlaşılmıştır.

Elde edilen bu sonuçlar, yatırımcılar, portföy yöneticileri, risk yöneticileri, ekonomi yönetimleri ve dövizle işlem yapan işletmeler açısından önemli sonuçlar ortaya çıkarmıştır. Oynaklık yayılımlarının hangi varlıklar arasında nasıl gerçekleştiği, CDS primlerinin oynaklık yayılımlarında önemli bir faktör olarak ortaya çıkması portföy yönetimi ve çeşitlendirme ile portföy riskini yönetme açısından önemli sonuçlar sunmaktadır. BIST 100'ün döviz kurundan (KUR) oynaklık yayılımı alması, faiz ve CDS primleriyle negatif yönde oynaklık ilişkisinin olması, BiST pay piyasası yatırımlarını doğrudan ilgilendirmektedir. Döviz kuru, faiz ve CDS primlerindeki hareketlere göre pay piyasası yatırımcıları portföylerini düzenlemelidirler.

\section{Beyan ve Açıklamalar (Disclosure Statements)}

1. Bu çalıșmanın yazarı, araştırma ve yayın etiği ilkelerine uyduğunu kabul etmektedir (The author of this article confirms that her work complies with the principles of research and publication ethics).

2. Yazar tarafından herhangi bir çıkar çatışması beyan edilmemiştir (No potential conflict of interest was reported by the author).

3. Bu çalışma, intihal tarama programı kullanılarak intihal taramasından geçirilmiştir (This article was screened for potential plagiarism using a plagiarism screening program).

\section{Son Notlar}

1. DCC GARCH modeli Tablo 3'de verilen GARCH(1,1) modelinin uzantısıdır.

2. https://setav.org/assets/uploads/2018/04/Rapor_TEM.pdf 13.04.2020

\section{Kaynaklar}

Akardeniz, E., \& Engin, C. (2019). TCMB faiz kararlarının döviz kuru volatilitesine etkisi. Finansal Araştırmalar ve Çalışmalar Dergisi, 11(20), 1309-1123.

Akkuş, H. T., Sakarya, Ş., \& Tüzün, O. (2018). Tahvil faizleri ile CDS primleri arasındaki oynaklık yayılım etkilerinin belirlenmesi. Bankacılar Dergisi, (104), 41-54.

Assefa, T. A., Esqueda, O. A., \& Mollick, A. V. (2017). Stock returns and interest rates around the World: A panel data approach. Journal of Economics and Business, 89, 20-35.

Baklacı, H. F., Aydoğan, B., \& Yelkenci, T. (2020). Impact of stock market trading on currency market volatility spillovers. Research in International Business and Finance, 52, 1-27.

Balcilar, M., Hammoudeh, S., \& Toparli, E. A. (2018). On the risk spillover across the oil market, stock market, and the oil related CDS sectors: A volatility impulse response approach. Energy Economics, 74, 813-827.

Belke, A., \& Gokus, C. (2011). Volatility patterns of CDS, bond and stock markets before and during the financial crisis: Evidence from major financial institutions. Roma Discussion Paper, 11-02.

Black, S. W. (2015). The portfolio theory of exchange rates - then and now. Review of Internaational Economics, 23(2), 379-386.

Bolaman Avcı, Ö. (2020). Interaction between CDS premiums and stock markets: Case of Turkey. Ömer Halis Demir Üniversitesi IïF Dergisi, 13(1), 1-8. 
Bollerslev, T. (1986). Generalized autoregressive conditional heteroskedasticity. Journal of Econometrics, 31, $307-327$.

Castellano, R., \& Scaccia, L. (2014). Can CDS indexes signal future turmoils in the stock market? A Markov switching perspective. Central European Journal of Operations Research, 22(2), 285-305.

Dai, Z., Zhou, H., \& Dong, X. (2020). Forecasting stock market volatility: The role of gold and exchange rate. AIMS Mathematics, 5(5), 50945105.

Dornbusch, R., \& Fischer, S. (1980). Exchange rates and current account. American Economic Association, 70(5), 960971.

Engle, R. F. (1982). Autoregressive conditional heteroscedasticity with estimates of the variance of United Kingdom inflation. Econometrica, 50(4), 987-1007.

Erdoğan, S., Gedikli, A., \& Çevik, E. İ. (2020). Volatility spillover effect between Islamic stock markets and exchange rates: Evidence from three emerging countries. Borsa Istanbul review.

Fonseca, J. D., \& Gottschalk, A. (2020). The co-movement of credit default swaps spreads, equity returns and volatility: Evidence from Asia - Pasific markets. International Review of Finance, 20(3), 551-579.

Fonseca, J. D., \& Wang, P. (2016). A joint analysis of market indexes in credit default swap, volatility and stock markets. Aplied Economics, 48(19), 1767-1784.

Frankel, J. A. (1992). Monetary and portfolio - balance models of exchange rate determination. In international economic policies and their theoretical foundations. Academic Press, 793-832.

Gök, I. Y., \& Arslan, Z. Kredi temerrüt swap spreadleri ve kredi derecelendirme duyuruları arasındaki ilişki: Gelişmekte olan ülkeler kapsamında bir araştırma. Uluslararası iktisadi ve Idari incelemeler Dergisi, (24), 301-314.

Hong, Y. (2001). A test for volatility spillover with application to exchange rates. Journal of Econometrics, 103, $183-224$.

Hurduzeu, G., Musetescu, R. C., \& Meghisan, G. M. (2015). Financial market reaction to changes in the volatilities of CDS returns. Romanian Journal of Economic Forecasting, 18(3), 152-165.

I, T. (2015). Study on return and volatility spillover effects among stock, CDS and foreign exchange markets in Korea. Journal of East Asian Economic Integration, 19(3), 275-322.

Kar, M., Bayat, T., \& Kayhan, S. (2016). Impact of credit default swaps on volatility of the exchange rate in Turkey: The case of Euro. International Journal of Financial Studies, 4(3), 1-18.

Kasman, S., Vardar, G., \& Tunç, G. (2011). The impact of interest rate and exchange rate volatility on bank' stock returns and volatility: Evidence from Turkey. Economic Modeling, 28(3), 1328-1334.

Kurt Cihangir, Ç. (2020). Volatility spillover effects from global and national variables to sovereign CDS spreads: Evidence from Turkey. Süleyman Demirel Üniversitesi Vizyoner Dergisi, 11(26), 45-61.

Lee, H.C., Hsu, C.H., \& Chien, C. Y. (2016). Spillovers of international interest rate swap markets and stock market volatility. Managerial Finance, 42(10), 943-962.

Liu, H. H., \& Chen, S. H. (2016). Nonlinear relationships and volatility spillovers among house prices, interest rates and stock market prices. International Journal of Strategic Property Management, 20(4), 371-383.

Mateev, M. (2019). Volatility relation between credit default swap and stock market: New empirical tests. Journal of Economics and Finance, 43(4), 681-712.

Mateev, M., \& Marinova, E. (2019). Relation between credit default swap spreads and stock prices: A non-linear perspective. Journal of Economics and Finance, 43(1), 1-26.

Morales-Zumaquero, A., \& Sosvilla-Rivero, S. (2018). Volatillity spillover between foreign exchange and stock markets in industrialized countries. The Quarterly Review of Economics and Finance, 70, 121- 136

Mouna, A., \& Anis, J. (2017). Stock market, interest rate and exchange rate risk effects on non financial stock returns during the financial crisis. Journal of the Knowledge Economy, 8(3), 898-915.

Öztürk, L., \& Türkay, H. (2005). Aşırı değer içeren veri kümelerinde hata terimlerinin binom dağılıma uyduğu durumda EKK ve robust LTS regresyon tahmincilerinin simulasyon çalışması ile karşılaştırılması. Süleyman Demirel Üniversitesi i.i.B.F. Dergisi, 10(1), 263-279.

Ross, S. A. (1989). Information and volatility: The no-arbitrage Martingale approach to timing and resolutioan irrelevancy. Journal of Finance, 44(1), 1-17.

Shahzad, S. J. H., Aloui, C., \& Jammazi, R. (2020). On the interplay between US sectoral CDS, stock and VIX indices: Fresh insights from wavelet approaches. Finance Research Letters, 33, 101208.

Shear, F., \& Butt, H. A. (2017). Relationship between stock and the sovereign CDS markets: A panel VAR based analysis. South Asian Journal of Management Sciences, 11(1), 52-67. 
Siddiqui, S., \& Roy, P. (2019). Predicting volatility and dynamic relation between stock market, exchange rate and select commodities. Acta Universitatis Agriculturae et Silviculturae Mendelianae Brunensis, 67(6), 1597-1611.

Singhal, S., Choudhary, S., \& Biswal, P. C. (2019). Return and volatility linkages among international crude oil price, gold price, exchange rate and stock market: Evidence from Mexico. Resources Policy, 60, 255-261.

Sui, L., \& Sun, L. (2016). Spillover effects between exchange rates and stock prices: Evidence from BRICS around the recent global financial crisis. Research in International Business and Finance, 36, 459-471.

Taştan, H., \& Güngör, A. (2019). Türkiye hisse senedi piyasa volatilitesinin makroekonomik temelleri. Business and Economics Research Journal, 10(4), 823-832.

Tule, M., Dogo, M. ve Uzonwanne, G. (2018). Volatility of stock market returns and the naira exchange rate. Global Finance Journal, 35, 97-105.

Yaman, S., \& Korkmaz, T. (2020). Döviz kurları ile BisT turizm endeksi getirileri arasındaki volatilite yayılım etkisinin belirlenmesi. Business and Economics Research Journal, 11(3), 681-702

Zankawah, M., \& Stewart, C. (2019). Measuring the volatility spillover effects of crude oil prices on the exchange rate and stock market in Ghana. The Journal of International Trade \& Economic Development, 29(4), 420-439. 